\title{
Foreign Intelligence and Pharmaceutical Industry in Poland. Part 2
}

\author{
M. Sikora
}

For citation: Sikora M. Foreign Intelligence and Pharmaceutical Industry in Poland. Part 2. Vestnik of Saint Petersburg University. History, 2021, vol. 66, issue 1, pp. 260-278.

https://doi.org/10.21638/11701/spbu02.2021.116

In the 1960s, Polish society was still not affected by lifestyle diseases to such a large extent as in the developed countries of Western Europe. However, the statistics on cancer and cardiovascular diseases started to rise in the 1970s, along with the dynamic economic development of Poland under communist party's secretary Edward Gierek. Meanwhile, the government of the People's Republic of Poland could not afford to invest simultaneously in all critical sectors of the economy. Particular priority was given to capital-intensive automotive and electronics industries as well as to traditional but important for Polish exports of raw materials (copper, coal). In the 1980s, as a result of the Cold War escalation along with the subsequent tightening of the strategic embargo by NATO states, and - finally - because of the gigantic foreign debt, the financial resources of Poland were reduced almost to zero. The lack of funds for research and development in the field of pharmacy and biotechnology was to be compensated for by an illegal transfer of know-how from the OECD area. Polish foreign intelligence services had already considerable experience in the field of purchasing technical documentation on the black market. In the 1970s, at least a dozen or so antibiotic manufacturing technologies were clandestinely obtained in the West and passed on to the Polish R\&D and industry. The article examines the involvement of Polish intelligence in the transfer of medicines, active substances and other pharmaceutical products (including medical equipment) to Poland. The "socially useful" function of communist secret services becomes a fascinating problem in this context. The article is based partly on the documents produced or collected by the Polish foreign intelligence service in 1960-1990, which have been declassified and are now accessible to the public in the Archive of the Institute of National Remembrance.

Miroslaw Sikora - PhD, Senior Specialist, Institute of National Remembrance, Office for History Research, Regional Branch, 102, ul. Józefowska, Katowice, 40-145, Poland; miroslaw.sikora@ipn.gov.pl; miroslaw.sikora@yandex.com

Мирослав Сикора - PhD, ст. специалист, Институт национальной памяти, Управление исторических исследований (региональный филиал), Польша, 40-145, Катовице, ул. Жозефоувска, 102; miroslaw.sikora@ipn.gov.pl; miroslaw.sikora@yandex.com

This research was funded by National Science Center (NCN), Poland, Project Sonata, Edition 13, No: 2017/26/D/HS3/00250.

Исследование финансировалось Национальным научным центром (NCN), Польша, Project Sonata, издание 13, №: 2017/26/D/HS3/00250.

I would like to express my gratitude to Mark Kramer (Davis Center for Russian and Euroasian Studies) for his positive feedback and numerous comments which helped me to improve the scientific and stylistic quality of this article.

Я хотел бы выразить благодарность Марку Крамеру (Центр исследований России и Евразии Дэвиса) за его положительные отзывы и многочисленные комментарии, которые помогли мне улучшить научное и стилистическое качество этой статьи.

(C) St. Petersburg State University, 2021 
Keywords: Poland, Cold War, Comecon, intelligence services, scientific espionage, pharmaceutical industry, history of technology.

\section{Внешняя разведка и фармацевтическая промышленность в Польше. Часть 2}

\section{М. Сикора}

Для цитирования: Sikora M. Foreign Intelligence and Pharmaceutical Industry in Poland. Part 2 // Вестник Санкт-Петербургского университета. История. 2021. Т.66. Вып. 1. С.260-278. https://doi.org/10.21638/11701/spbu02.2021.116

В 1960-х гг. польское общество еще не было затронуто болезнями образа жизни в такой степени, как в развитых странах Западной Европы. Однако статистика рака и сердечно-сосудистых заболеваний начала расти в 1970-х гг. вместе с динамичным экономическим развитием Польши при первом секретаре коммунистической партии Эдварде Гереке. Правительство Польской Народной Республики не могло позволить себе одновременное инвестирование во все важнейшие секторы экономики. Особое внимание уделялось капиталоемкой автомобильной и электронной промышленности, а также традиционным, но важным для польского экспорта сырьевым отраслям (медь, уголь). В 1980-х гг. в результате эскалации холодной войны и последующего ужесточения стратегического эмбарго странами НАТО, а также из-за гигантского внешнего долга финансовые ресурсы Польши сократились практически до нуля. Недостаток средств для исследований и разработок в области фармации и биотехнологий должен был быть компенсирован незаконной передачей ноу-хау из зоны Организации экономического сотрудничества и развития. Польские службы внешней разведки уже имели значительный опыт в области закупки технической документации на черном рынке. В 1970-х гг. не менее десятка технологий производства антибиотиков были тайно получены на Западе и переданы польским научно-исследовательским и промышленным предприятиям. Статья содержит информацию о причастности польской разведки к переброске в Польшу лекарств, активных веществ и других фармацевтических продуктов (в том числе медицинского оборудования). В этом контексте общественно полезная функция коммунистических спецслужб становится интересной проблемой. Статья частично основана на документах архива Института национальной памяти, подготовленных или собранных польской службой внешней разведки в 1960-1990 гг., которые были рассекречены, а в настоящее время доступны для публичного использования.

Ключевые слова: Польша, холодная война, СЭВ, спецслужбы, научно-техническая разведка, фармацевтическая промышленность, история техники.

Capabilities and Modus Operandi. According to the calculations of Jerzy Metera - Director of the Committee of Science and Technology at the government of the Polish People's Republic (PPR) in the sixties - the critical transition from the moment of launching research works to the stage of implementation of an invention (for instance, drugs) into mass production lasted on average in Comecon states from as long as 15 years (for technologies subjected to basic research) to 10 years (for technologies subjected to applied research) and possibly 5 years (for improvised implementations). Meanwhile, the implementation of the purchased license allowed for a shortening of the time interval for the preparation of the production and marketing of the drug to only 2 years ${ }^{1}$. More or less the same timespan was required to roll out stolen technology.

1 Wilczynski J. Technology in Comecon: Acceleration of Technological Progress through Economic Planning and the Market. London, 1974. P. 89. 
In order to steal technologies effectively and on a relatively large scale, it was necessary to educate, equip, and keep a large staff of officers assigned to the Polish Scientific-Technical Intelligence branch (STI, WNT in Polish - Wywiad Naukowo Techniczny). When staff is taken into consideration, the Division II of WNT (changed to Division V in $1977^{2}$ ) working on biotechnology and pharmacy, was weaker than the two other divisions of scientific-technological intelligence, i.e., Division VI (1973-1977 as III) working on microelectronics and computer science, and also Division VII (earlier IV) which took up heavy industry (metallurgy, natural resources' exploitation).

In the seventies and eighties on average, a total number of approximately 20-30 officers worked in the Division II/V (not including secretaries) ${ }^{3}$. Some employees were temporarily (for example over a period of 4 years) moved from the HQ in Warsaw to the cover institutions or to the foreign workplaces (embassies). Not all from the Division staff worked in the area of pharmacy. Some of them were assigned to cases concerning basic research on genetics. Halfway through the seventies the process of spying on R\&D-centers in the field of genetic engineering all over the world (especially EEC countries, India, US, and Japan) was on the way ${ }^{4}$. Moreover, among cases realized by Division II/V, there was also biological and chemical weaponry ${ }^{5}$. Furthermore, there were genetically modified fodders (steroids), fertilizers, pesticides, herbicides, other agricultural uses of biotechnology $^{6}$, plastics (polymers) ${ }^{7}$, dyes, varnishes, glues, and other building materials ${ }^{8}$, before, finally, the petroleum industry ${ }^{9}$.

Poles were obviously not the only actors of that emerging field of illicit technology flow. In addition to other socialist countries, there were also western ones involved in such an industrial espionage. US multinationals, such as Eli Lilly Schering-Plough or Merck and many others, fell under constant surveillance of French, West-German or French intelligence services or competing corporations ${ }^{10}$.

Proportionally to personnel and organizational forces, Division II/V realized one third fewer cases than Division III/VI and Division IV/VII, and a half more cases than

2 The reorganization was not due to the plan but was made suddenly because of the defection of one of the Polish intelligence officers and subsequent disclosure of numerous details of Department I's organization to the BND and CIA same year.

${ }^{3}$ Wyniki pracy wywiadu naukowo-technicznego MSW PRL 1971-1989 / ed. by M. Sikora. Katowice; Warsaw, 2019.

${ }^{4}$ See: case crypt. "Bioin" // Archive of the Institute of National Remembrance [Warsaw] (AIPN), sign. 02320/462. See also: case crypt. "Prax" // AIPN, sign. 01592/215. The latter addressed the task of manufacturing tryptophan repressor (operon), mutants with that repressor and enzymes MetRS, TyrRS, and T3Pol. It was, moreover, launched at the request of KGB.

5 Compare cases crypt. "Mojra” // AIPN, sign. 01593/180; “Danala," 02320/553; “Alund," 01593/158; and "Pocisk," 01593/157.

6 Compare cases crypt. "Skrobia" // AIPN, sign. 01593/156; "Roślina," 01592/187; "Freon," 01592/62; "Reon," 01592/63; "Round," 01593/733; "Rosen," 01593/970; "Loters," 01593/971; and "Rynapoz," 01824/196.

7 Compare cases crypt. "Piła" // AIPN, sign. 01227/406; "Gdańsk," 01237/350; "Włocławek," 01227/403; “Police," 01237/349; “Polietylen," 01227/404; “Tapra," 01285/757; “Etamin,” 01592/184; “Latexo," 01583/612; and "Sino," 01593/954.

8 Compare cases crypt. "Lokrad” // AIPN, sign. 01592/423; “Diaben,” 01592/402; "Laker," 01593/884; "Budowa," 01593/289; “Cement," 01593/290; “Kleje," 01789/261; “Lepik," 01593/880; “Gasol," 01593/952; and "Anben," 01593/956.

9 Compare cases crypt. "Piroliza” // AIPN, sign. 01793/67; and "Inal," 01793/68.

10 Schweizer P.Szpiedzy wśród przyjaciół. Jak Sojusznicy wykradają Amerykanom tajemnice technologiczne / transl. J. Lobman, Z. Słomkowski. Warszawa, 1997. P. 13, 17, 21, 23-25, 27, 29, 34, 44, 126, 134-135, 137, 183, 224, 290-292, 298. 
Division V/VIII (economic espionage). Among about 1,400 operational tasks of WNT registered in 1973-1990, about one fifth (about 250-300) could have been realized by officers of Division II/V. Within analyzed research sample of 220 tasks, about 45 tasks belonged to Division II/V.

Division II/V had a team of workers in the Ministry of Chemical (and Light) Industry similar to the team working for Divisions III/VI and IV/VII inside the Ministry of Metallurgy and Machine Industry. They performed their duties under the cryptonym "Chemia"11. It is less probable that Division II/V had external workers in the Ministry of Health and Social Care (Ministerstwo Zdrowia i Opieki Społecznej - MZiOS). Probably the transmission of demands of that ministry to MSW was done within its managing staff, through mediation of personal sources of information, recruited directly by Department I (intelligence service) and its local units (so called inspectorates I) respectively by establishing in 1979 Department III-A (renamed in 1981 to Department V MSW) with its local units responsible for protection of economy and banking institutions ${ }^{12}$ or by Department III responsible for invigilation of academic environments ${ }^{13}$. The direct contacts between Ministry of Internal Affairs (MSW) and Ministry of Health were rather rare. Ties between the Ministry of Health and Social Care and MSW were, for sure, maintained over various $\mathrm{R} \& \mathrm{D}$ institutions. For example, by the end of the eighties, there was so called Initiation Center for Needs of Healthcare "Biotechnika" communicating directly with Department I on behalf of Ministry of Health ${ }^{14}$.

Formulating tasks for Department I proceeded according to the same bureaucratic method since 1973 until the end of communist MSW. The appropriate minister - basically of the chemical industry - came to the minister of internal affairs with a motion to "give help with buying, by secret means, technical-technological documentation of medicine called..." In the same message, basic obligatory categories of documentation were included, such as: 1) the technological description of the process of making a medicine, 2) the characteristics of basic apparatuses required to carry out such a process, 3) the characteristics of necessary stock/elements, 4) so called stock and energetic balance, and 5) the description of process analytics. These were of special of interest to Polish scientists. The inseparable elements of this motion were the economic justification of the request to gain medical technology and a presentation of the benefits to the Polish treasury. Routinely, there were discussions concerning the prospect of reducing costly imports from western countries with a possibility to increase profitable export to Comecon countries ${ }^{15}$. From the MSW cabinet the message was sent right away to Department I, and from there, it was

11 Compare briefcase of so-called domestic intelligence's residency crypt. "Sputnik" / "Polver" // AIPN, sign. 01789/211 and 02320/419.

12 Sikora M. Służba Bezpieczeństwa MSW a system bankowy PRL w dobie przekształceń gospodarczych drugiej połowy lat osiemdziesiątych XX w. Wstęp do analizy zagadnienia // Studia Polityczne PAN. 2012. Vol. 30. P. 109-158.

13 Compare papers of Adam Dziuba about University of Silesia and article of Mirosław Sikora concerning Technical University of Silesia in: Myśl na uwięzi. Kontrola operacyjna środowisk akademickich województwa katowickiego przez Służbę Bezpieczeństwa w latach siedemdziesiątych i osiemdziesiątych XX wieku. Studia i szkice / eds A. Dziuba, M. Sikora. Katowice, 2010. P.99-137, 256-315.

${ }^{14}$ Initiation Organization Center for Needs of Healthcare "Biotechnika" to the chief of Department I of Ministry of Internal Affairs colonel Henryk Jasik, Warsaw, 1990. March 23 // AIPN, sign. 02271/23. P. 56. - In 1991 "Biotechnika" was absorbed by OBR of Biotechnology.

15 See, for example: Minister of chemical and light Industry Edward Grzywa to Minister of internal affairs, general of arms Czesław Kiszczak, Warsaw, 1986. January 4 // AIPN, sign. 01824/23. P. 10. 
delivered to the proper division. In this particular case, it was Division II/V appointed to obtain the medicines. The operation was officially sanctioned after registration in Card Index of Tasks of WNT Department I. The task's time limit was determined in various ways. It was intended to be about one year but could have been prolonged if necessary, for even a couple of years ${ }^{16}$.

In Division II/V, on the basis of the analysis of operational assets, i.e. officers, agents, informational contacts, and other secret co-workers (for instance, consultants of other security service departments, who were in scholarships, internships, or were doing research in western companies or pharmaceutical institutes) the possibility of illegal ways of capturing the medicine's recipe was estimated. Next, there was a message sent to the desk of the minister of chemical industry from the under-secretary of state in MSW, who was responsible for intelligence oversight. It contained information about the possibility of gaining a medicine (if such a possibility existed) and about conditions of acquisition of such a medicine. This meant, de facto, the sum of money (foreign currencies), which the bidder (agent) wanted for the technology, and predicted operational costs (officers' travel, accommodation, etc. $)^{17}$. In some cases, the officers of Division II/V knew about a case before it was officially given to them. This took place when the intelligence itself took up the initiative and not the ministry. It happened when by coincidence some operative abroad managed to acquire an interesting asset (i.e., recruit valuable source/agent) offering access to a pharmaceutical factory, biotechnological institute, or medical university, where important drugs were developed. In such a situation, officers of the foreign intelligence stations instantly informed the workers of Division II/V in the homeland. They, in turn, inspired their colleagues from the "second line" placed in secret job positions in the Ministry of Chemical [and Light] Industry (Ministerstwo Przemysłu Chemicznego [i Lekkiego] - MPCh(iL) $)^{18}$ to recognize Polish pharmacy's demand for the products of the institution being infiltrated by the promising agent. When such demand was confirmed, the minister of the Chemical Industry addressed the MSW with the above discussed motion.

The next stage was preparing and realizing the deal with the agent, the shipment of the documentation to the country, and, finally, submitting the documentation to Polish specialists for evaluation. These specialists were appointed by intelligence officers or possibly other organizational cells of the Security Service. The scientists were obliged to keep their insight into the documentation secret. In the meantime, original signs, such as the company's logo or the organization's letterhead, that could lead to their source of origin were removed from the records by the intelligence workers. If the initial analysis had a positive result, the Ministry of Chemical Industry or the Ministry of Agriculture and Forestry in the case of fertilizers, fodders, and crop protection means ${ }^{19}$ transferred into the bank account of Department I in Bank Handlowy SA the formerly agreed sum of money ${ }^{20}$. Such accounts

16 Chief of Division V to the deputy chief of Department I of Ministry of Internal Affairs - report about expressing agreement to introduce to Card Index of Tasks and realization of intelligence task, Warsaw, 1986. February $11 / /$ AIPN, sign. 01824/23. P. 11.

17 General of division Władysław Pożoga to the minister of chemical and light industry, comrade prof. dr engineer Edward Grzywa, Warsaw, 1986. February 18 // AIPN, sign. 01824/23. P. 12.

18 The Ministry of Chemical Industry has been extended by addition of light industry in 1982.

19 Chief of Division V to Chief of Division XIX of Department I, Warsaw, 1988. March 8 // AIPN, sign. 02271/23. P. 11; Chief of Division V to Chief of Division XIX of Department I of Ministry of Internal Affairs, Warsaw, 1989. December 15 // AIPN, sign. 02271/23. P. 56.

${ }^{20}$ Deputy chief of Division V to deputy chief of Department I of Ministry of Internal Affairs - report on realization of intelligence task, Warsaw, 1986. December 20 // AIPN, sign. 01824/23. P. 20. 
were usually disguised as foreign-currency accounts of the Bureau of Scientific-Technical Development and Implementations ${ }^{21}$. In the case of any difficulties from the implementation to production of a secretly bought technology, the possibility of further consultations with the seller (agent) was expected. This even included a possible transfer to the country. They would get in touch with Polish specialists as advisers. The problem of legalizing technologies smuggled from the West to PPR, which were protected by international law regulations in the field of intellectual property, was probably resolved by registering an allegedly new patent in Poland by a Polish R\&D-unit or private persons ${ }^{22}$.

Among companies "attacked" in the seventies and eighties by the PPR's intelligence were those from Western Europe, mainly from FRG, Austria, France, Switzerland, or Italy, although the cables also show intelligence's interest in American companies. In the first half of the sixties, several operations whose objectives were defined according to the criterion of company (facility) were launched. The goal here was not to capture any concrete technologies (drugs, active substances etc.) but to penetrate into the structures of the producers long-term, for instance, into E. I. du Pont de Nemours in the US ${ }^{23}$ or Imperial Chemical Industries in Great Britain ${ }^{24}$. Both mentioned cases were, however, closed by 1984 without having achieved any significant successes in infiltration of targeted corporations. Since the mid-seventies, tasks concerning precise defined solutions (medicines) and not companies had been prioritized by the intelligence's leadership.

Operations in the area of pharmacy. It is intriguing that information confirming the intensified activity of Division II of Directorate VII in the first years of functioning had not been found. Jobs from the industry were implemented in mass only by the end of 1976, taking the form of the individual brief cases, which, in turn, were assigned to an object's thorough study. It was a sort of mother-case-cryptonym "Iryd". Those brief-cases (tasks) had cryptonyms "Biopol”, "Apa", "Penicyl", "Ryfak", "Erytrot", and "Cefa"25. They were all successfully realized and finished with desired antibiotic products brought to Poland. Unfortunately, for most of these cases, it is not possible to assess operational costs and expected profits from the implemented solutions. This is due to the lack of accessible records.

The essence of the interaction between the industry and the intelligence was contained in a note prepared by an intelligence officer, placed under cover in the Foreign Cooperation Department of the Ministry of Chemical Industry, addressed to the minister in 1979 in connection with the operation code-named "Biopol”. It reads: "In 1978, the Polfa Pharmaceutical Industry Association held talks with the American company Cyanamid on the intensification of Tetracycline production. American specialists inspected the installation in the Tarchominskie Zakłady Farmaceutyczne 'Polfa' and agreed to intensify production on condition that the necessary modernization of the installation was carried out. For its know-how and antibiotic strain, Cyanamid demanded 100 thousand USD and a share in the increase in Tetracycline production over 5 years in the total amount of $67000 \mathrm{~kg}$, worth 1691000 USD. The effect of the project will be a significant increase in

${ }^{21}$ Under-Secretary of State in the Ministry of Finance to the manager of administration of Bank Handlowy SA, Warsaw 1989 May 27 // AIPN, sign. 02271/23. P. 54.

${ }^{22}$ More on patent-policy in PPR see: Wilczynski J. Technology in Comecon... P. 77-86.

23 See: case (operation) crypt. "Koncern/Pietra" // AIPN, sign. 01227/774.

24 See: case (operation) crypt. "Imper/Pineta" // AIPN, sign. 01227/775.

25 Case files have been archived under the following signatures: AIPN, sign. 02320/462, 01285/759, 01285/760, 01285/761, 01285/763, and 01592/38, respectively. 
production intended for export in convertible currency. It is assumed that the increase in production was: in the first year of application $33000 \mathrm{~kg}$ (value of 840000 USD), in the second year of application $50000 \mathrm{~kg}$ (value of $1279500 \mathrm{USD}$ ), in the third year of application $114000 \mathrm{~kg}$ (value of 2865100 USD). The Department of International Cooperation informed ZPF 'Polfa' that it is possible to obtain by the secret means an industrial strain and complete know-how for the biosynthesis of the Tetracycline with parameters identical to those offered by Cyanamid. The cost, including any technical support, will not exceed 200000 USD. Due to the fact that with identical production results and investment requirements, the proposal of the Department of International Cooperation is cheaper by about 2.5 million USD due to the difference in the cost of purchase of the strain and knowhow in the amount of 800000 USD and due to the lack of necessity to repay the goods in the amount of about 1.7 million USD - ZPF 'Polfa' requested the purchase of the strain and know-how through secret channels" 26 .

Another task ("Erytrot") brought savings of about 600000 USD a year and required expenditures of only 75 thousand USD for the purpose of "black market" operation ${ }^{27}$. The operations which started in 1976 continued until 1983, although many of abovementioned tasks were realized already by the second half of the seventies. In 1983, the next big series of operations aimed at bringing up-to-date and effective antibiotics technologies was launched. This time, records were far more detailed. Tasks, documented as so-called thematic cases cryptonyms "Penaz", "Fumeno", "Inox", and "Nezon"28 brought about savings of over eleven million USD a year, with the costs of the technology's transfer to Poland being 550 thousand USD in total. The operations mentioned as well as other cryptonyms - "Przemiana", "Doksa", and "Axon"29 - not only had characteristics of anti-import but also led to pro-export effects, enabling Poland enter the capitalist markets. The operation "Axon" which began later than others, in 1986, created the possibility of exporting medicines to the Soviet market for the approximate value (due to an official Comecon exchange-rate of transfer ruble) of eighteen million USD a year, and to the western markets - for twelve million USD a year ${ }^{30}$. Some of the operations were canceled due to delays in their realization or other reasons ${ }^{31}$.

A model example of an operation to support "Polfa" by STI is the operation codenamed "Doksa". Its subject was an antibiotic called Wibramycin (Doksycycline), produced by chemical synthesis from Oxytetracycline. Another antibiotic, Rondomycin, was ob-

${ }^{26}$ Memo for minister of chemical industry Henryk Konopacki, Warsaw, 1979. January 19 // AIPN, sign. 01285/759. P. 11-12; Minister of chemical industry to the minister of internal affairs general of division Stanisław Kowalczyk, Warsaw, 1979. March 16 // AIPN, sign. 01285/759. P. 21.

27 Under-Secretary of State in Ministry of Chemical Industry to Under-Secretary of State in Ministry of Internal Affairs brigadier-general Mirosław Milewski, 1976. December 11 // AIPN, sign. 01285/763. P. $10-11$.

${ }^{28}$ Case files have been archived under the following signatures: AIPN, sign. 01592/32, 01593/1038, 01593/1044, and 01593/968, respectively.

${ }_{29}$ Case files have been archived under the following signatures: AIPN, sign. 01593/1045, 01592/31, and $01592 / 352$, respectively.

${ }^{30}$ Minister of chemical and light industry Edward Grzywa to general of arms Czesław Kiszczak, 1987. April 30 // AIPN, sign. 01592/352. P. 14; Deputy chief of Division V to deputy chief of Department I of Ministry of Internal Affairs - report on realization of intelligence task, 1987. September 8 // AIPN, sign. 01592/352. P. 15.

${ }^{31}$ See: Report on registering out of Card Index of intelligence task No.949/V/84 - Chief of Division V to deputy chief of Department I of Ministry of Internal Affairs, Warsaw, 1986. May 21 // AIPN, sign. 01593/934. P. 13. 
tained as an intermediate product. "Polfa" had two technologies of vibramycin extraction, including one of its own with $30 \%$ efficiency and a license (Pfizer) with $50 \%$ efficiency. However, the latter technology required the use of liquid hydrogen fluoride as a medium. The use of this catalyst, in turn, entailed technical difficulties, which "Polfa" wanted to eliminate. The demand for technology bypassing the use of liquid hydrogen fluoride in the middle of 1984 was reported by TZF "Polfa" to the Ministry of Chemical Industry, from where it was sent to the Ministry of the Internal Affairs. Traditionally, it encompassed: a technological description of the process, characteristics of basic equipment, quality and sources of basic raw materials, material and energy balances, as well as problems of waste and sewage treatment. The task was registered in the intelligence file and accomplished in the summer of 1984 as a result of cooperation between Polish intelligence officers in Italy and Switzerland. The costs of the operation related to the fee paid to the agent and to the transport of the documentation package amounted in total to 90 thousand USD ${ }^{32}$.

The eighties also brought a series of operations aimed at other than antibiotics products of pharmaceutical industry: vaccines, medications for heart, immunological mixings, painkillers, or syringes (operations crypt. "Szczepion", "Pathyl", "Spiro", "Poxen", and "Syringe") ${ }^{33}$. Generally, the expenses and profits were lower than those in the antibiotics sector. Most of the operations were closed until 1987. Furthermore, in 1984 Division XIV of the Department I, which was overseeing the so-called illegals program, began to support intelligence's operations in the area of antibiotics, vaccines, and enzymes. Officers under false identity were ordered to penetrate into the major multinationals: Bayer and Boehringer in West Germany, Sandoz and Ciba Geigy in Switzerland and Austria, and finally Pfizer and Monsanto in the US ${ }^{34}$.

Sharing intelligence with partners. It is also noteworthy that apart from its own operations, there was also intelligence-interchange with Comecon countries, especially with the USSR, that could be very helpful for Polish industry.

After receiving a request for technology of the so-called Totally Artificial Heart (TAH) from the KGB during the 1980s, Polish intelligence not only acquired technical documentation of the First Generation's TAH in 1982 in Italy but also started to collect data on the Second Generation, tracking that area of science until the end of the $1980 \mathrm{~s}^{35}$. Interestingly, Division V was not in charge of that operation; it was realized by Division VI (IT/microelectronics) consulting with scientists from the Institute of Bio-cybernetics and Biomedical Engineering of the Polish Academy of Sciences in Warsaw.

The KGB's foreign intelligence service, according to the established pattern, most likely received this task from the Committee of Science and Technology of the Presidium of the USSR Council of Ministers, which mediated the transmission of topics from the industry and research and development sector to the intelligence service, as was done in Poland with the participation of the Committee for Technology in the 1960s, and the Office

32 The Plan for the realization of task "Doksa", Warsaw, 1984. June 8 // AIPN, sign. 01592/31. P.5; Report of deputy chief of Division V for the deputy chief of Department I, Warsaw, 1984. July 7. P. 13 // AIPN, sign. 01592/31.

33 AIPN, sign. 02320/387, 01824/23, 01929/36, 01929/38, 01592/181, and 02320/234, respectively. P. 6-12.

34 Agenda for operation crypt. "Chemikon", Warsaw, 24 August 1984 // AIPN, sign. 02320/245. Vol. 1.

35 Chief of Division [VI] of Department I of Ministry of Internal Affairs to chief-inspector of Inspectorate for SB KSMO (Security Service Capital City Headquarters of Civil Militia) in Warsaw, Warsaw, 1982. August 24 // AIPN, sign. 02320/234. Vol. 2. P. 55 passim. 
of Scientific and Technical Progress and Implementation in the second half of the 1980s. The aim of the operation was to obtain the construction and technical documentation together with the assembly (implantation) instructions as well as to obtain photographs of the TAH prototype. Getting a copy of the device itself was probably impossible.

The operation was registered in the Department I task file only in the early 1982: in the year when the attempt to implant TAH into a human being was completely successful for the first time. This was done by a team led by Robert Jarvik, based on previous years' research by Willem Johan Kolff (creator of the artificial kidney) from the University of Utah. This technology had also been developed for years in Europe.

The original TAH was made of polyurethane and so called light alloys (e.g. aluminum), and was covered with an elastomer Avothane. The device, measuring $12.5 \times 11.5 \times 10.5 \mathrm{~cm}$ and weighing about $1 \mathrm{~kg}$, was sewn to the heart atria as a substitute for the heart chambers responsible for pumping blood into the cardiovascular system (impact range 70 to 130 per minute). Control and power supply was provided by two Indiana General electronic motors $(73 \mathrm{~W} ; 27$ thousand $\mathrm{rpm}$ ). Apart from the implant itself, the set included a computer controlling the operation of the device ${ }^{36}$.

The Soviet Institute of Transplantation and Artificial Organs, a hypothetical beneficiary of the Polish WNT operation, concentrated its work on two subjects: kidney implant and heart implant. Therefore, the research was also undertaken on problems such as surgery, chemo-dialysis, anesthesiology, immunogenetics, resuscitation, electro-cardio pacemakers and biocybernetics. The evident intensification of the Institute's work on the technology of the so-called Total Artificial Heart (TAH), including heart ventricular prostheses made of polyurethane and elastomer, occured in the second half of the 1980s - early 1990s (clinical research) ${ }^{37}$. In 1986, in the USSR the law was changed so that from now on it was possible to collect the heart organ for transplantation from a patient diagnosed with "death of the brain". The first successful transplant in the USSR took place on March 12, 1987. In 1990, the patient was still alive. The 1990 report states that 45 heart transplants were performed between 1986 and $1990^{38}$.

TAH was not an exception. There were more operations realized for the demands of the USSR ${ }^{39}$. In the eighties, the scope of Moscow's interest covered mainly anticancer medicines ${ }^{40}$, medications for heart, antibiotics, and prophylactic and diagnostics for AIDS (results of patients' treatment, medical records, elaborations on treatment results, tests, and statistical data from companies) ${ }^{41}$. Furthermore, KGB's foreign intelligence was looking for X-ray apparatus, technical devices for computer tomography, endoscope technology, electrocardiogram and encephalography technology, laser surgery, electromagnetic

36 Memo on TAH, Warsaw, 1983. February 9 // AIPN, sign. 02320/234. Vol. 1. P.9-10.

37 Compare: Nauczno-Issledowatielskij institut transplantologii i iskusstwiennych organow Ministierstwa zdrawoochranienija SSSR, fond 260 // RGANTD opis 1-1 (1978-1991), delo 25, 73, 79, 81, 83-86, 97, 98, 104-106, 108, 110, 116, 117, 120, 121, 126, 140, 142.

38 Referat „Transplantacja Sierdca”, RGANTD opis 1-1 (1978-1991), delo 140, P.3-4.

39 Orientirowka-Zadanie po prioritetnoi probleme 215: tekhnicheskie sredstwa, materialy i oborudowanie primeniaemye dlia diagnostiki lechenija boleznei cheloweka, n. p., 1989. October 24 // AIPN, sign. 02271/21. Vol. 6. P. 24-40.

40 Memo No. 10151/PPR, Warsaw, 1989. February 13 // AIPN, sign. 02271/21, Vol. 5. P. 285.

41 Memo concerning information gained during discussion with Soviet delegation on the subject of their interest in the field of genetic engineering, Warsaw, 1989. February 14 // AIPN, sign. 02271/21. Vol.31. P. 51-52; Translation of the KGB's USSR memo No. 1451, 1988. September 29 // AIPN, sign. 02271/21. Vol. 17. P.35-36; Memo No.9156/PPR, Warsaw, 1987. January 29 // AIPN, sign. 02271/21. Vol. 20. P. 445. 
physiotherapy, technologies in service of anesthesiology, transplantation, blood transfusion, and many others ${ }^{42}$. Some of those technologies were captured by Polish STI and passed on to Russians after receiving reimbursement.

These funds not only covered the costs of the acquisition of certain products but also were an additional source of income for Polish intelligence. It happened when WNT had purchased technology by its agent abroad and then offered it to the KGB at a higher price than the money paid to the agent.

Every year, there were several dozen chemical and biotechnological solutions, among them pharmaceuticals, being interchanged between MSW and KGB. For instance, in 1987, Moscow received 80 "solutions" (in terms of information packages/batches; basically 1 batch stood for 1 item, for instance: technical documentation/technological documentation/description of medicine or a chemical substance/user manual/blueprint etc.) and offered Warsaw approximately 200 of them ${ }^{43}$. Altogether, it was more than both partners exchanged in the area of IT and microelectronics that year. From May 1988 to May 1989, Division V acquired from KGB's STI an additional 180 "solutions" and passed ten times less onto the USSR ${ }^{44}$.

The main beneficiary of Polish intelligence's operations in the field of pharmacy was without a doubt Poland and not the USSR. The reason behind it was that even if the KGB was the real customer, including the reimbursement of money, the Polish officers often made copies before anding off documents to Russian colleagues. Those copies were passed on to Polish R\&D-representatives afterwards. It is not that obvious in the case of tasks realized by Division III/VI aimed at informatics and electronic solutions of military character. Most of modern microelectronic components were useless for the backward Polish arms industry to implement but could be absorbed by the well-developed Soviet military complex.

Poland's sharing of clandestine information with other partners within Comecon was smaller compared to that with the USSR. In addition to the KGB, the most valuable data came from the so-called Sektor für Wissenschaft und Technik (SWT) i. e., STI of the East Germany's Stasi. With regards to IT and microelectronics, there was a substantial discrepancy between the demands of Polish and East German STI, which, in turn, reflected different needs of both economies. In the area of chemistry and biotechnology, there were a lot of common tasks with which each STI was charged by industry and R\&D. During the debriefing of representatives of WNT and SWT in East Berlin in autumn of 1987 illegal acquisition of technologies, such as genetically produced insulin, interferons, peptides, and biolipids, as well as HIV/AIDS-diagnostics were discussed ${ }^{45}$.

42 Orientirowka-Zadanie po prioritetnoi probleme 215: tekhnicheskie sredstwa, materialy i oborudowanie primeniaemye dlia diagnostiki lechenija boleznei cheloweka, n. p., 1989. October 24 // AIPN, sign. 02271/21. Vol. 6. P. 24-40.

${ }^{43}$ Memo-summary of STI-interchange between MSW and First Main Directorate of KGB USSR in the period of time 1 November 1986 - 31 December 1987, Warsaw, 1988. January 21 // AIPN, sign. 02271/21. Vol. 21. P. 445-449.

${ }^{44}$ Summary of STI-interchange between MSW and First Main Directorate of KGB USSR in the period of time 1 May 1988 - 31 May 1989 and attachments, Warsaw, 1989. June // AIPN, sign. 02271/21. Vol. 31. P. 10-24.

${ }^{45}$ Report on meeting with representatives of SWT MfS GDR 28 September 1987 - 1 October 1987, Warsaw, 1987. October 23 // AIPN, sign. 02271/21. Vol.11. P. 41-44. 
Similarly, the relation between WNT and its Soviet counterpart showed huge disproportions between WNT and SWT regarding the information being shared. For instance, from summer 1987 to spring 1989, Polish intelligence received from East German colleagues 72 "solutions" which made up approximately 35 percent of the entire STI-data transfer from the GDR to Poland. However, only 4 "solutions" were delivered to the East Germans. Among the technologies obtained by Poles were documents regarding advanced computer utility software, for example, a program for the modeling of proteins' structure, program "Midas" for design of molecules' surface, and automatic control of the fermentation process ${ }^{46}$.

Analytical skills of intelligence applied in health care. Case study HIV/AIDS. Nonetheless, there was also an analytical work performed by intelligence that cannot be simply figured out and expressed in financial terms. An instructive example of that kind of support was the case referring to HIV/AIDS. Surely, in the eighties, the human immunodeficiency virus/syndrome was a worldwide sensation in a sphere of healthcare. Nowadays, the etiology of HIV/AIDS can be looked upon enriched with many years of experience ${ }^{47}$. The level of society's knowledge about the disease from the beginning of the eighties pictured aptly in the Robert Zemeckis's movie "Forrest Gump" - is presented in a brochure in 1986 by the Polish Academy of Sciences (PAN) in a series "Science for Everyone" ("Nauka dla Wszystkich"). It informs that "within 5 years since AIDS appeared in the US, more than 17,000 cases of illness were recorded, more than 2,000 in Western Europe, and probably a dozen or so thousand in the countries of Equatorial Africa" ${ }^{48}$. This moderately distressing data given to the public by PAN differed from the intelligence information collected in the following years for the purpose of the cabinets of Prime Ministers Zbigniew Messner (1985-1988) and Mieczysław Rakowski (1988-1989). According to intelligence data from 1988, hundreds of thousands, perhaps even more than a million people could possibly have been infected with the virus worldwide ${ }^{49}$.

It is worth stressing that information on HIV/AIDS delivered by intelligence, although not by STI-branch, was collected due to a particular agenda and not accidentally. In 1987, Warsaw-center (Department I) sent certain tasks to intelligence's residences abroad concerning methods of fighting HIV/AIDS applied by governments of various countries from Euro-Atlantic region, Latin America, Africa, India, and South-East Asia ${ }^{50}$. The goal of intelligences was to obtain specimens and solutions serving HIV/AIDS diagnostics and to figure out which medical centers and companies were doing the research on vaccines. Intelligence's attention also covered the costs of governmental programs to pro-

${ }^{46}$ Summary of STI - interchange between MSW and SWT MfS GDR in the period of time 1 September 1987 - 31 May 1989, Warsaw, 1989. June // AIPN, sign. 02271/21. Vol. 11. P.3-6.

47 In 2010, there were about 34 million HIV carriers worldwide, of which 5 million were in the USA and in Europe. In the same year, 1.8 million people in the world died of AIDS, including 200,000 in the USA and in Europe. These numbers are according to Global HIV/AIDS Response: Epidemic Update and Health Sector Progress towards Universal Access, Progress Report 2011. URL: http://www.who.int/hiv/pub/ progress_report2011/en/ (accessed: 11.08.2020).

48 Skotnicki A. B. AIDS: Nabyty Zespół Zaniku Odporności. Wroclaw, 1986. P. 3.

49 Memo concerning AIDS, Chicago, 1988. February 10 // AIPN, sign. 0449/26. Vol. 30. P. 18-24.

50 Compare: Cable No. 789, Bangkok, 1989. January 26// AIPN, sign. 0449/26. Vol. 30. P. 16-17; Memo concerning danger of AIDS in Nigeria, Lagos, 1988. January 9 // AIPN, sign. 0449/26. Vol.30. P.25-26; Cable No. 10997, Havana, 1987. December 9 // AIPN, sign. 0449/26. Vol.30. P.47-48; Cable No. 10047, New Delhi, 1987. November 13 // AIPN, sign. 0449/26. Vol.30. P. 50-51; Cable No. 9410, Tripoli, 1987. October 27 // AIPN, sign. 0449/26. Vol. 30. P. 52-54. 
tect societies against the virus and the geopolitical implications of a possible pandemic for the NATO-countries, especially the US. Some forecasts predicted a growth in the number of HIV carriers in the US to be twenty million people by 1991, and in Western Europe, for the same period, - about 10 million people ${ }^{51}$. For instance, in one analysis delivered to the Polish government it was reported that the American blood reserves could have been infected, which in turn was of great importance in the case of a possible military conflict ${ }^{52}$.

Parallel to intelligence's involvement in demands to broaden the range of knowledge, the government of PPR began to make preparations for a potential need to fight the epidemic in Poland. In September 1985, the Minister of Health and Social Care appointed Brigadier-General Prof. Jerzy Bończak to the post of the plenipotentiary for the AIDS disease. Furthermore, the Minister assigned a team of scientists under the manager of the Institute of Immunology of National Institute of Hygiene Prof. Adam Nowosławski to work on the AIDS problem. By February 1986, that team selectively had examined about nine thousand people classed among risk groups, ascertaining in fourteen blood samples the presence of HTLV-III antibodies. It did not prove that one would fall ill with AIDS but confirmed the fact that there had been contact with HIV and that some hormonal responses of the organism in the form of antigens had succeeded ${ }^{53}$.

Probably in the sphere of recognition of the worldwide research on medicines (vaccines) against HIV, intelligence played only a secondary role. Preventing pandemic was in the interest of all countries. In relation to this, co-operation rather than competition might have been expected between governments, even those from antagonizing blocs, and exerting pressure by those governments on pharmaceutical companies to share their patents (of course in the form of paid licenses) with countries of Eastern Europe and the "third world". The readiness of the western countries to share experience in fighting the disease results from contacts established by MZiOS with the specialists from FRG and Belgium in $1985^{54}$, with the Swedish Karolinska Institute Department of Infectious Diseases in $1987^{55}$, or from the participation of the Polish delegation in the council of the First International Conference on the Global Impact of AIDS in London in $1988^{56}$.

Intelligence gathering did not matter in the case of AIDS as much in the case of antibiotics, considering only an insignificant state of advancement of worldwide research on pharmacological prevention of AIDS in the eighties. In summary, there were no interesting, effective, clinically tested, and patented technologies, which could have been

51 Brigadier-General Zdzisław Sarewicz — Information Department I to the country's government concerning estimations of danger for western countries' societies with AIDS disease, n.p., n.d. // AIPN, sign. 0449/26, Vol.30. P. 37-40.

52 Report from intelligence station concerning political and economic implications of AIDS in the USA, 13 August 1987 // AIPN, sign. 0449/26. Vol. 30. P. 88-89. There is no evidence for any direct connection existing between the data collection on HIV/AIDS in the Polish intelligence and the parallel purported Soviet AIDS-disinformation campaign orchestrated by KGB worldwide. Compare: Selvage D., Nehring Ch. Die AIDS-Verschwörung: Das Ministerium für Staatssicherheit und die AIDS-Desinformationskampagne des KGB // BF informiert. 2014. No.33. P.21-25.

53 Skotnicki A. B. AIDS. P. 60.

54 Report on scientific travel to FRG and Belgium in November 1985, n.p., n. d. // Central Archive of Modern Records (AAN), Ministry of Health and Social Care, sign. 19/1199. P.215-218.

55 Report on the visit at Karolinska Institute Department of Infectious Diseases in Stockholm in October 1987, Warsaw, 20 October 1987 // AAN, Ministry of Health and Social Care, sign. 19/1200. P. 22-24.

56 Report on participation in The First Conference on the Global Impact of AIDS in London in March 1988, n. p., n. d. // AAN, Ministry of Health and Social Care, sign. 19/1200. P.34-36. 
purchased or stolen. Moreover, HIV was, at that time, not as a serious a problem for the Polish government as it was in some other European countries.

Economic results. In August 1986, the Minister of the Chemical and Light Industry Edward Grzywa wrote to the First Secretary KC PZPR (Central Committee of the Polish United Workers' Party) army General Wojciech Jaruzelski, referring to the realization of resolution number $36 / 85$ concerning increasing the speed of pharmaceutical development of PPR: "A number of technologies of production, modern medicines, and medical equipment, which were not produced in the country until now, were worked out including: amikacin, cefuroxime, propylphenazone, methyldopa. Parallel implementation of new generations of highly effective technologies of production of pro-export antibiotics, such as erythromycin, penicillin, rifampicin, succeeded. I want to stress that a major advancement of works in the industry in the abovementioned subjects were only possible thanks to the help of scientific-technical intelligence of MSW. It delivered the records and strains that were impossible to acquire officially or that the purchase of which would have required foreign currency expenses of many millions" 57 .

The officers working for the scientific-technical branch of communist intelligence hoped to survive the perturbations of the summer of 1989. Solidarność had won the election and began to disassemble the security service (Służba Bezpieczeństwa), of which Department I and STI-branch were an organic part. The STI's command emphasized the indispensable role played by this branch of intelligence in the entire Polish economy. The advantages highlighted in reports mailed to various members of the new government included the Polish pharmaceutical industry. In one memo, addressed to Prime Minister Tadeusz Mazowiecki, the director of the Department I, Brigadier-General Zdzisław Sarewicz wrote, "There have been following technologies acquired and delivered to the industry: 1) new generation anticancer drugs, highly effective and very expensive - Daunorubicin, Adriamycin, Pharmorubicin. The hitherto import of those specifics enabled treatment of no more than 60 percent of cancer patients." 2) amikacin - an antibiotic of a so called "life rescuing medicines" applied in cases of serious infections. The production of this drug had already started in a pharmaceutical plant in Kutno, "Polfa", and will soon enable the cancellation of import and development of profitable export" 58 .

And exactly - how much money, especially valuable foreign currencies, did the efforts of Polish intelligence save? To estimate profits from a successful transfer of much desired know-how to Poland, it is necessary to take into account three long-term components. They were: 1 ) reduction of import, mainly from the so called second payment territory (OECD and others); 2) increase of export, mainly to the countries of the so called first payment territory (Comecon); and 3) savings of time, personnel, material, and finance in own R\&D.

Although the records of MSW along with files of MZiOS and MPCh(iL) investigated so far do not give a definite assessment of expenses and profits, they enable to sketch some selective or general conclusions of financial nature. Let us take a look at several numbers.

57 Minister of chemical and light industry to first secretary of Central Committee of Polish United Workers' Party, chief of Council of State of Polish People's Republic comrade army General Wojciech Jaruzelski, Warsaw, 1986. May 8 // AIPN, sign. 02271/21. Vol. 15. P. 204.

58 Ministry of Internal Affairs Department I (intelligence) - Memo on the intelligence's operations in the area of economy, science and technology, Warsaw, 1989. September // AIPN, sign. 02271/21. Vol.21. P.4-7. Compare: Żukowski E. Wybrane zagadnienia biotechnologii antybiotyków // Antybiotyki. Współczesny stan wiedzy. Warsaw, 1990, P. 188-189. 
In the years 1971-1975, investment expenditures in R\&D submitted to MPCh(iL) (in total, in pharmacy, fertilizers, steroids, plastics, synthetic fibers, paints, varnishes, chemical products for the household, building chemistry, petroleum, rubber industry, chemical reagents, and others) were about 3.7 billion zlotys in total. Prognosis for the next five-year period was: 1976-1980 - six billion, 1981-1985 - 6.9 billion, 1986-1990 - 8.1 billion zlotys. Within 20 years, it gave a total of eight billion USD due to the official rate. However, it was only 250 million USD due to black market rate. Within this budget, there was a plan to assign "Polfa" in subsequently four periods of five years respectively: 250 million zlotys, 600 million zlotys, 700 million zlotys, and 750 million zlotys. It made up within twenty years a total of about 720 million USD officially. This too was only 23 million USD on the black market ${ }^{59}$. What was the average yearly value of the Polish pharmaceutical industry? For example, Central Plan for the Year 1986 expected national production in the range of pharmaceutical products and sanitary articles to be 41 billion zlotys (market prices). This would have been 500 million USD at that time $e^{60}$.

The value of medicines imported from the socialist countries (excluding Yugoslavia) at the beginning of the seventies shaped itself in the following figures: $19714-5$ million, 1972 - 60 million, and 1973 (prognosis) - 70 million zlotys in foreign currencies (socalled zloty dewizowy, which was a mixed rate of official rates of western currencies: USD, GBP, DM, CHF, etc.) ${ }^{61}$. The value of import from capitalist countries (including Yugoslavia) ${ }^{62}$ was in the analogical years: 22 million, 32 million, and as a prognosis -28 million zlotys in foreign currencies respectively ${ }^{63}$.

In the year 1973, when WNT clearly involved itself in supplying the country with imported medicines, expenditures amounted to 100 million zlotys in foreign currencies. This was about 30 million USD according to the official exchange rate. In general, the Polish import of medicines from OECD increased three times in the seventies in comparison to the sixties ${ }^{64}$. It was an axiomatic proof of growing dependence on western producers. This

${ }^{59}$ Investment expenses for rebuilding agencies of scientific-research and development base, and the purchase of scientific research apparatus (assessment) - appendix no. 1 to the scientific description: prognosis of development of scientific research agencies of chemical industry to the year 1990, n.p. 1975 // AAN, Ministry of Chemical Industry, sign. 22/2 [lacks page number].

${ }^{60}$ Estimation of supplying the country in medicines and sanitary articles, Warsaw 1986 // AAN, Ministry of Health and Social Care, sign. 19/610. P. 4.

${ }^{61}$ The official, i. e., regulated by the government of the People's Republic of Poland (PRL), exchange rate of the dollar to the so-called "foreign exchange zloty" (in fact zloty was not a convertible currency) in 1970 was 1 to 4 . It was reduced in the following years of the decade to the level of about 1:3 in 1980. In the 1970s, however, the price of one USD on the black market was about 100 zloty and was closer to its real value. As a result of economic and social perturbations and the announcement of a moratorium on debt repayment to creditors (mainly from OECD countries), the National Bank of Poland revalorized and made real the dollar exchange rate (the distinction between foreign exchange and circulation zloty was abolished), setting it at $1 \mathrm{USD}=68 \mathrm{zl}$ in 1981. After a short period of stabilization, the value of the zloty against the USD decreased on average by several dozen zloty a year, reaching the level of 1 USD $=500 \mathrm{zl}$ in December 1988 .

62 Yugoslavia played - apart from Hungary in socialist bloc - a key part in import of medicines by PPR. For example, only for importing of preparation called nifedipin (for the needs of a cardiology medicine cordafen) and only in the year 1986 Yugoslavia was paid 12 million USD, until this medicine - at the end of the eighties - was introduced into production in Polish plants, thanks to R\&D in IF. 60 lat Instytutu Farmaceutycznego 1952-2012 / eds W. Szelejewski, T. Paszkowska-Reymer. Warsaw, Studio Bąk, 2012, P. 21.

63 Plan of import of medicines for the year 1974 - material for council, n.p., 1973. May 12 // AAN, Ministry of Health and Social Care, sign. 15/13. P.1.

${ }^{64}$ Basic questions of the pharmacy department, n.p., 1973. June 22 // AAN, Ministry of Health and Social Care, sign. 15/15. P. 19. 
trend was maintained in the course of the eighties. Undoubtedly, it was of somewhat natural in the face of the growing global commodities exchange and expansion of international markets. The import of pharmaceutical products and sanitary articles from the countries of the first payment territory (Comecon) designed in 1986 for 1987 was 127 million transfer rubles, which, according to the exchange value of transfer ruble to USD, was equal to almost 70 million USD, and the import from the second payment territory (capitalist countries) was almost 105 million USD. Despite this, the mixed team of representatives of MZiOS and MPCh(iL) demanded an increase of limits of foreign currencies to trade with the OECD of additional 60 million USD (!). They had important trump cards: in 1986, out of almost 380 pharmaceutical intermediates figuring in Official List of Medicines (which included a total of about 1900 positions), 50 were imported from capitalist countries; and out of more than 1050 ready-made medicines (also included in the mentioned list) even 230 were imported from the West (and from the Comecon countries - only 90) ${ }^{65}$.

More detailed structure of foreign purchases of the Polish government shows interesting trends. In the "plan of import of medicines from capitalist countries in the year 1974", 40 million zlotys in foreign currencies (złoty dewizowy) was to be divided within eighteen therapeutic groups. The - most 4.5 million - was spent on a group of antibiotics (mainly ampicillin, colimycin, keflin, lincocin, and rovamycine). Almost the same price had to be paid for a group of antimycobacterial, which included mainly ethambutol, rifampicin, and capreomycin (4.5 million). Another important position, though very far from both previous ones, as far as expenses are concerned, was occupied by such therapeutic groups as psychiatry and neurology ( 2.5 million), and serums, vaccines, and diagnostic specimens ( 2.1 million $)^{66}$. These statistics help us to understand the interest of Polish intelligence in antibiotics (two first groups). The Ministries of Health and Chemistry simply needed stronger financial support from the government in this particular sphere. The government itself, out of insufficient funds, decided to take advantage of the clandestine undertakings. Moreover, possible profits for the national treasury flowing from the export of pharmaceutical products captured thanks to the intelligence's service, were tempting for the government.

It is unfortunately extremely difficult to estimate intelligence's contribution to trade capacity of PPR in the area of pharmaceutical commodities. As a bare outline of a range of that phenomenon, it can be mentioned that only in 1973 the value of "Polfa's" export to the socialist countries was over 360 million zlotys in foreign currencies (about 110 million USD due to official rate), and to the capitalist countries -84 million zlotys in foreign currencies (about 26 million USD due to official rate) ${ }^{67}$. Those were certainly vital sums for the country's treasury.

There were of course costs involved related to maintenance of infrastructure in Division II/since 1977 V of the Department I, its staff and outlay. Operating expenses (travel, meetings with agents, keeping secret communications) accounted for approximately $50 \%$

${ }^{65}$ Estimation of supplying the country with medicines and sanitary articles, Warsaw 1986 // AAN, Ministry of Health and Social Care, sign. 19/610. P. 4, 8, 9, Appendix 4.

${ }_{66}$ Plan of import of medicines for the year 1974 - material for council, n.p., 1973. May 12 // AAN, Ministry of Health and Social Care, sign. 15/13. P.9-11.

67 The value of total production of "Polfa" in 1973 was 6.6 billion zlotys (market prices). See: Basic questions of the department of pharmacy, n.p., 1973. June 22 // AAN, Ministry of Health and Social Care, sign 15/15. P. 10, 12 . 


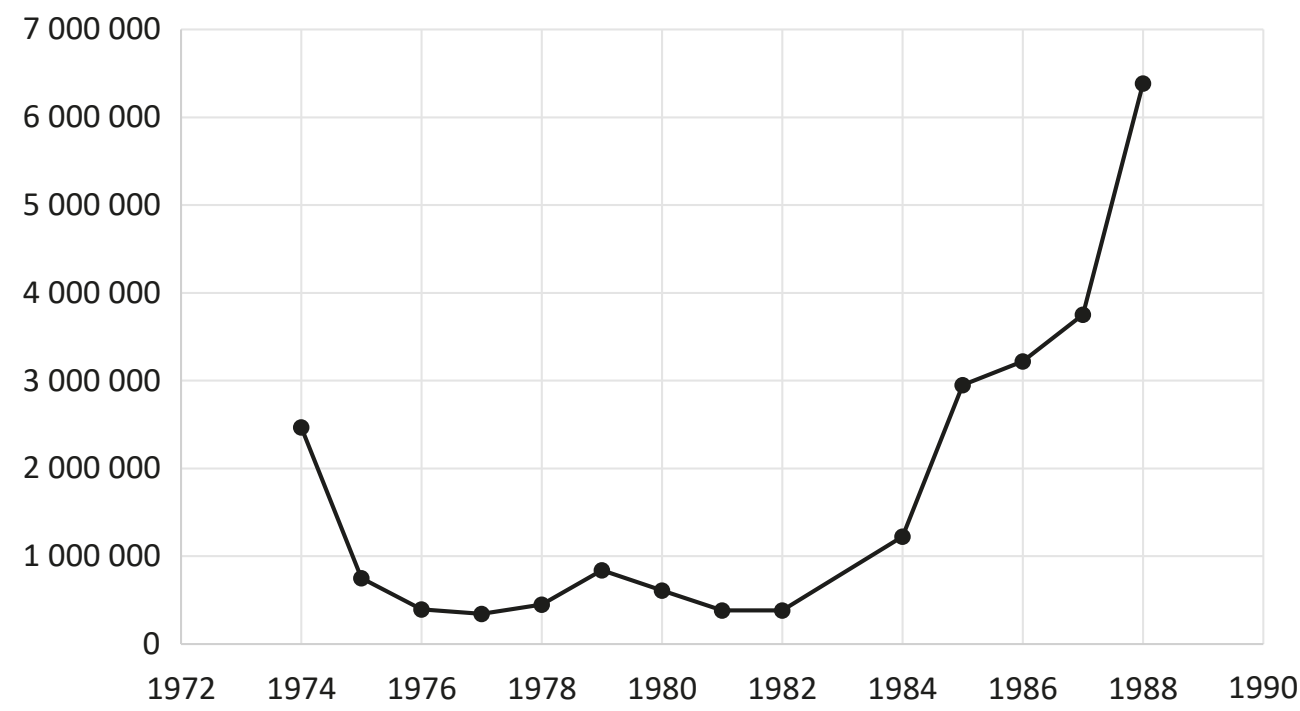

Chart. Operating expenses of Division II/V (chemistry and biotechnology) of Department I in 1974-1988 (Polish Zloty - zl) [Financial reports and analysis of Department I: AIPN, sign. 01741/52. P.22; sign. 01741/54. P.20; sign. 01741/56. P.16; sign. 01741/58. P.17; sign. 01741/60. Vol.1. P.18; sign. 01741/62. Vol. 1. P. 20; sign. 01741/64. Vol. 1. P. 17; sign. 01741/66. Vol. 1. P.21; sign. 01741/68. Vol.1. P. 18; sign. 01741/70. Vol.1. P.17; sign. 01741/74. Vol.1. P.18; sign. 01741/76. Vol.1. P.18; sign. 01741/78. Vol. 1. P. 19; sign. 01741/80. Vol.1. P. 19; sign. 01741/83. Vol. 1. P.21; sign. 01741/85. Vol. 1. P.21]

of the department's expenses. The rest consisted of officers' salaries, social welfare and other typical personnel expenses.

During the years 1960-1990 there were two peaks of the chemical division's activity (compare the section on operations in the area of pharmacy earlier in this article) - one in mid-70s and the second one in mid 80s, which are quite well reflected in the budget statistics. Normal annual operating costs amounted from half a million to one million zloty (see chart). However, an accelerating inflation in the late 80 s has to be taken into consideration when analyzing and comparing those two peaks.

Conclusion and Research Prospects. In conclusion, it can be carefully stated that the role of intelligence in supplying the sector of public healthcare in PPR with various kinds of medicines, especially antibiotics, beginning from the second half of the seventies was non-trivial. The aid from intelligence brought about measurable economic effects, which is at least in some areas possible to be quantified in the present times. Secret and illegal gaining of the medical products were done according to a pattern worked out in the sixties and taught to future officers of Division II/V of WNT at the Center for Training of the Intelligence Staff (OKKW) in the seventies. It did not vary much from the methods used by other divisions of scientific-technical intelligence. It is doubtless that a proper definition of tasks for Division II/V and a successful implementation of the technology obtained was each time an effect of cooperation between many people, including not only those who were connected with intelligence directly (officers in covert and secret job positions) and 
indirectly (co-operating people/so called TW, consultants, etc.) but also a whole mass of specialists and clerks who did not realize they were involved in covert operations. The ingenious machines of technology which stole, although quite efficiently, in the end signified an economic and general system crisis for countries of the socialist bloc. The gap in technological development became evident in the period of the so-called political détente, which was accompanied by an unprecedented technological advance in the West. The reason and circumstances of the collapse of the Comecon were aptly expressed by Francis Fukuyama. "While centrally planned economies could follow their capitalist counterparts into the age of coal, steel, and heavy manufacturing, they were much less able to cope with the requirements of the information age. In fact, it was in the highly complex and dynamic 'post-industrial' economic world that Marxism-Leninism as an economic system met its Waterloo"68.

It would be an interesting postulate for the future research to recognize the Polish WNT's cooperation with its counterparts in other Comecon countries. Could there be a possible division of tasks within the socialist intelligence community in the sphere of the clandestine acquisition of medicines, as it happened in the legal sphere of $\mathrm{R} \& \mathrm{D}^{69}$ ? It seems that specializing in infiltration of certain countries and companies or in reaching certain people in those countries and companies could result in measurable profits for the whole Warsaw Pact (Comecon). In this area questions also remain on details of refinancing intelligence's expenses to buy medicines on the "black market." It is now known that the compensation of operational expenditures was settled in a form of a foreign currency transfer done by a proper ministry official (the Chemical Industry, possibly of Health) from one of the secret accounts of Department I opened in Bank Handlowy SA. Such accounts were set up based on the demands of each separate task ${ }^{70}$. Funds for covert operations were probably coming from the ministerial (MPCh(iL) respectively MZiOS) budget assigned for supporting research and development works. It is also not known how Department I received money. There was, for sure, an opportunity for a quasi-legal acquisition of some additional funds from industry and R\&D for often political or military goals of the Polish intelligence's community on occasion of STI's activity.

Perhaps in the future the image of the Security Service, of which civil intelligence was a part, transferred to the modern society and subsequent generations will yield some corrections. As a result, Służba Bezpieczeństwa (SB), previously perceived from a point of view of the society's interests only as a counter-productive institution, bolstered the communist party by resisting democratic liberties and the market economy. It harassed opposition leaders, invigilated the Catholic church and even ordinary citizens. It could show

${ }^{68}$ Fukuyama F. Koniec Historii / trans. by T. Bieroń and M. Wichrowski. Poznan, 1996. P. 141.

69 The official works were coordinated in areas such as antibiotics, steroids, antimycobacterials, anticancer medicines, circulatory system medicines, and psychotropic medicines. See: Report of Polish delegation on XI session of Work Group of pharmaceutical industry of Comecon countries - Budapest 11-17 November 1969, n.p., n.d. // AAN, Ministry of Health and Social Care, sign. 19/1198. P.48-58; Report on delegation to Romania - XV conference of Group of Pharmaceutical Industry of Comecon countries and Yugoslavia in 1973 with the appendix - propositions of specialization of certain socialist countries in the area of ready-made medicines, n.p., n.d. // AAN, Ministry of Health and Social Care, sign. 19/1198. P. 64-71.

70 See financial records of Division V, for example: Deputy chief of Division [V] to chief of Division XIX of Department I of Ministry of Internal Affairs, Warsaw, 1989. February 20 // AIPN, sign. 02271/23. P. 43. 
its different side of a Janus face, more "productive" from the point of view of the public interest. Studies on selective aspects of the involvement of MSW in fighting various categories of economic crimes in state companies, joint-ventures, and in banking institutions during the seventies and eighties of the twentieth century, have been already published ${ }^{71}$.

Perspectives of policy making, macro-economy, military affairs, or social science are standard components of classical approach in history. It has to be stressed that research led by historians in such remote areas of science as engineering, mathematics, or chemistry, could easily cause mistakes. It is obvious because of the limited capabilities of the human mind that it is not possible to cover details of several disciplines of science at the same time. But interdisciplinary studies are inevitable regarding the topic of intelligence in the area of science and technology. They are the only tool that enable to explain this "missing dimension"72 of the modernization process in the socialistic block. By this statement, this paper tries to follow the call of the renowned explorer of the interaction between science, technology, and society Paul Edwards who claims: “...multiscalar analysis holds the key to an understanding of technology and modernity, we must at least make the attempt"73.

\section{References}

60 lat instytutu farmaceutycznego 1952-2012. Eds W. Szelejewski, T. Paszkowska-Reymer. Warsaw, Studio Bąk, 2012, 162 p.

Black I., Morris B. Israel's Secret Wars: A History of Israel's Intelligence Services. New York, Grove and Weidenfeld, 1991. $603 \mathrm{p}$.

Edwards P.N. nfrastructure and Modernity: Force, Time, and Social Organization in the History of Sociotechnical Systems. Modernity and Technology. Cambridge, MIT Press, 2003, pp. 185-226.

Fukuyama F. Koniec Historii. Poznan, Wydawnictwo Zysk i S-ka, 1996, 307 p.

Selvage D., Nehring Ch. Die AIDS-Verschwörung: Das Ministerium für Staatssicherheit und die AIDSDesinformationskampagne des KGB. BF informiert. 2014, no. 33, pp. 21-25.

Schweizer P. Szpiedzy wśród przyjaciół. Jak Sojusznicy wykradają Amerykanom tajemnice technologiczne. Warsaw, Książka i Wiedza, 1997, 359 p.

Sikora M. Koncesjonowany kapitalizm. Służba Bezpieczeństwa MSW a „spółki polonijne” w PRL (19761989). Dzieje Najnowsze PAN, 2012, vol. 45, no. 2, pp. 125-146.

Sikora M. Służba Bezpieczeństwa MSW a system bankowy PRL w dobie przekształceń gospodarczych drugiej połowy lat osiemdziesiątych XX w. Wstęp do analizy zagadnienia. Studia Polityczne PAN, 2012, vol. 30, pp. 109-158.

Sikora M. Służba Bezpieczeństwa wobec przekształceń ekonomicznych w Polsce 1980-1989. Przyczynek do badań nad ingerencją polskich służb specjalnych w gospodarkę. Pamięć i Sprawiedliwość. 2012, vol. 20, pp.359-410.

Skotnicki A. B. AIDS: Nabyty Zespół Zaniku Odporności. Wroclaw, Ossolineum, 1986. 63 p.

${ }^{71}$ For the results of preliminary researches on the meaning of Security Service for protection of interest of the treasury of Poland and on the part of Security Service in fighting financial abuse, embezzlements and corruption in national companies and administration, see: Sikora M. Służba Bezpieczeństwa wobec przekształceń ekonomicznych w Polsce 1980-1989. Przyczynek do badań nad ingerencją polskich służb specjalnych w gospodarkę // Pamięć i Sprawiedliwość. 2012. Vol.20. P.359-410. - On the subject of interaction between Security Service and private sector with participation of foreign capital in PPR, see also: Sikora M. Koncesjonowany kapitalizm. Służba Bezpieczeństwa MSW a „spółki polonijne” w PRL (19761989) // Dzieje Najnowsze PAN. 2012. Vol.45, no. 2. P. 125-146.

72 Black I., Morris B. Israel's Secret Wars: A History of Israel's Intelligence Services. New York, 1991. P.XI.

${ }^{73}$ Edwards P. N. Infrastructure and Modernity: Force, Time, and Social Organization in the History of Sociotechnical Systems // Modernity and Technology. Cambridge, 2003. P. 224. 
Wilczynski J. Technology in Comecon: Acceleration of Technological Progress through Economic Planning and the Market. London, Macmillan Press, 1974, 379 p.

Wyniki pracy wywiadu naukowo-technicznego MSW PRL 1971-1989. Ed. M. Sikora. Katowice, Warsaw, IPN, 2019, $352 \mathrm{p}$.

Żukowski E. Wybrane zagadnienia biotechnologii antybiotyków. Antybiotyki. Współczesny stan wiedzy. Warsaw, Przedsiębiorstwo Wydawnictw i Wystaw Chemii Przemysłu Chemicznego i Lekkiego „Chemil", 1990, p. 495.

Статья поступила в редакцию 30 августа 2020 г. Рекомендована в печать 10 декабря 2020 г.

Received: August 30, 2020

Accepted: December 10, 2020 